\title{
Electrokinetic desalination of protruded areas of stone avoiding the direct contact with electrodes
}

Feijoo, J.; Matyscák, O.; Ottosen, Lisbeth M.; Rivas, T.; Novoa, X. R.

Published in:

Materials and Structures

Link to article, DOI:

10.1617/s11527-016-0946-x

Publication date:

2017

Document Version

Peer reviewed version

Link back to DTU Orbit

Citation (APA):

Feijoo, J., Matyscák, O., Ottosen, L. M., Rivas, T., \& Novoa, X. R. (2017). Electrokinetic desalination of protruded areas of stone avoiding the direct contact with electrodes. Materials and Structures, 50(82). https://doi.org/10.1617/s11527-016-0946-x

\section{General rights}

Copyright and moral rights for the publications made accessible in the public portal are retained by the authors and/or other copyright owners and it is a condition of accessing publications that users recognise and abide by the legal requirements associated with these rights.

- Users may download and print one copy of any publication from the public portal for the purpose of private study or research.

- You may not further distribute the material or use it for any profit-making activity or commercial gain

- You may freely distribute the URL identifying the publication in the public portal 


\section{Materials and Structures \\ Electrokinetic desalination of protruded areas of stone avoiding the direct contact with electrodes \\ --Manuscript Draft--}

\begin{tabular}{|c|c|}
\hline Manuscript Number: & MAAS-D-16-00173R2 \\
\hline Full Title: & $\begin{array}{l}\text { Electrokinetic desalination of protruded areas of stone avoiding the direct contact with } \\
\text { electrodes }\end{array}$ \\
\hline Article Type: & Original Research \\
\hline Keywords: & Electrokinetic technique; desalination; soluble salts; chloride; nitrate; sulphate \\
\hline Corresponding Author: & $\begin{array}{l}\text { Jorge Feijoo, PhD } \\
\text { Universidade de Vigo } \\
\text { Vigo, Pontevedra SPAIN }\end{array}$ \\
\hline \multicolumn{2}{|l|}{$\begin{array}{l}\text { Corresponding Author Secondary } \\
\text { Information: }\end{array}$} \\
\hline Corresponding Author's Institution: & Universidade de Vigo \\
\hline \multicolumn{2}{|l|}{$\begin{array}{l}\text { Corresponding Author's Secondary } \\
\text { Institution: }\end{array}$} \\
\hline First Author: & Jorge Feijoo, PhD \\
\hline \multicolumn{2}{|l|}{ First Author Secondary Information: } \\
\hline \multirow[t]{5}{*}{ Order of Authors: } & Jorge Feijoo, PhD \\
\hline & O. Matyščák, PhD \\
\hline & L.M. Ottosen, PhD \\
\hline & T. Rivas, PhD \\
\hline & X.R. Nóvoa, PhD \\
\hline
\end{tabular}

Order of Authors Secondary Information:

Funding Information:

\begin{tabular}{ll} 
Abstract: & $\begin{array}{l}\text { Soluble salts are considered one of the main deterioration factors of porous building } \\
\text { materials such as rocks, bricks or granites. The desalination treatments currently used } \\
\text { in order to mitigate this alteration process are usually applied directly on the affected } \\
\text { areas, which have often a low degree of cohesion precisely due to the deteriorating } \\
\text { effect of the salts. } \\
\text { The present study aimed to investigate the evaluation of a new approach based on } \\
\text { electrokinetic techniques to desalinate rocks in monuments, specifically to desalinate } \\
\text { carved reliefs. The procedure avoids the direct contact with the areas highly affected } \\
\text { by salts, which usually show loss of cohesion due to salt crystallization processes, by } \\
\text { placing the electrodes on adjacent areas less contaminated with salts. This fact } \\
\text { represents another difficulty in the desalination process because the electric field must } \\
\text { be adapted to the shape of the sculptural motif. An ashlar of sandstone highly } \\
\text { contaminated with salts in a protruded area located in its central part was used for this } \\
\text { purpose. } \\
\text { The results showed that the electrokinetic setup proposed allowed to achieve high } \\
\text { percentages of salt content reduction (above } 80 \%) \text { in the protruded area of the } \\
\text { sandstone highly contaminated with salts. Therefore, these results confirmed that it } \\
\text { was possible to desalinate the sandstone using electrokinetic methods without the } \\
\text { need to put in contact the affected areas with the equipment, reducing the possibility of } \\
\text { altering it by manipulation. }\end{array}$ \\
\hline Response to Reviewers: & $\begin{array}{l}\text { Editor in Chief } \\
\text { Materials and Structures } \\
\text { Vigo, } 1 \text { September } 2016\end{array}$ \\
\hline
\end{tabular}




\section{Electrokinetic desalination of protruded areas of stone avoiding the direct contact with}

2 electrodes

3 J. Feijoo*

4 Departamento de Enxeñaría dos Recursos Naturais e Medioambiente, E.T.S.I. de Minas,

5 Universidade de Vigo, Campus Lagoas-Marcosende, 36310 Vigo, Spain. jfeijoo@uvigo.es.

6 Phone: +34986812219

7

$8 \quad$ O. Matyščák

9 Department of Civil Engineering, Brno University of Technology. Veveři 331/95, 60200 Brno,

10 Czech Republic. ondrej.matyscak@seznam.cz

Department of Civil Engineering Building 117, Technical University of Denmark, 2800 Kgs.

14 Lyngby, Denmark. lo@byg.dtu.dk. Phone +45252260

16 T. Rivas

17 Departamento de Enxeñaría dos Recursos Naturais e Medioambiente, E.T.S.I. de Minas,

18 Universidade de Vigo, Campus Lagoas-Marcosende, 36310 Vigo, Spain. trivas@uvigo.es.

X.R. Nóvoa

21 Departamento de Enxeñaría Química; E.E.I. Industrial, ENCOMAT group

22 Universidade de Vigo, Campus Lagoas-Marcosende, 36310 Vigo, Spain. rnovoa@uvigo.es

$24 *$ corresponding author 


\section{Abstract:}

2 Soluble salts are considered one of the main deterioration factors of porous building materials

3 such as rocks, bricks or granites. The desalination treatments currently used in order to mitigate

4 this alteration process are usually applied directly on the affected areas, which have often a low

5 degree of cohesion precisely due to the deteriorating effect of the salts.

6 The present study aimed to investigate the evaluation of a new approach based on electrokinetic

7 techniques to desalinate rocks in monuments, specifically to desalinate carved reliefs. The

8 procedure avoids the direct contact with the areas highly affected by salts, which usually show

9 loss of cohesion due to salt crystallization processes, by placing the electrodes on adjacent areas

10 less contaminated with salts. This fact represents another difficulty in the desalination process

11 because the electric field must be adapted to the shape of the sculptural motif. An ashlar of

12 sandstone highly contaminated with salts in a protruded area located in its central part was used

13 for this purpose.

14 The results showed that the electrokinetic setup proposed allowed to achieve high percentages

15 of salt content reduction (above $80 \%$ ) in the protruded area of the sandstone highly

16 contaminated with salts. Therefore, these results confirmed that it was possible to desalinate the

17 sandstone using electrokinetic methods without the need to put in contact the affected areas with

18 the equipment, reducing the possibility of altering it by manipulation.

19 Keywords: Electrokinetic technique; desalination; soluble salts; chloride; nitrate; sulphate. 
1

\section{Introduction}

2 Soluble salts are considered one of the main alteration factors of the rocks used in cultural

3 building heritage; they are responsible for several deterioration forms, such as granular

4 disintegration or superficial detachments, which put in risk the conservation of this heritage and

5 thus the future transmission of its value.

6 The alteration mechanism related by soluble salts in rocks is essentially a physical process

7 based on the stress level generated by the crystallization of the salts in the pores (Charola et al

8 2007; La Iglesia et al 1997; Steiger 2005; Tsui et al 2003).

9 This alteration mechanism is favoured by alternative processes of wetting and drying of the materials, due to the water entering by capillary suction, periodic rainfall on structures and

11 changes in the relative humidity (Honeyborne 1998; Watt and Colston 2000). In this situation,

12 salts suffer alternative crystallization and dissolution processes, which help to the movement of

13 the salts through the pores. The crystallization of the salts in the pores causes a high pressure against the walls of the pores which can exceed the tensile strength of the material. As a result, a loss of cohesion between grain minerals is produced and a sand disaggregation and superficial detachments are developed (Cardell et al 2003; Charola 2000). These deterioration forms affect

17 the most superficial levels of the stones, since it is in these levels where the evaporation 18 processes are more intense and the salt content is the highest (Pel et al 2003). Due to the serious

19 consequences of this deterioration process on the conservation of the materials, the research studies focused on mitigating or combat the salt crystallization phenomena are abundant

21 (Lubelli and van Hess 2010, 2007; Ottosen and Rörig-Dalgaard 2007; Rivas et al 2010; Setina and Kirilova 2012; Unhruh 2001).

23 The treatments currently used in order to minimize the effect of the salts in monuments or 24 structures are the desalination by means water immersion baths, poultices or electrokinetic techniques among others. The last two techniques, more applicable to immovable works, involve (especially in the case of the desalination by poultice) a direct contact between the surfaces affected by salt action and the desalination devices (poultices or electrodes). This direct 
1 contact entails a risk of loss of surface material when the rock is affected by the loss of cohesion

2 typically associated to the effect of salts. This contact could also involve colour changes

3 associated with the interaction of these devices with the rock material, such as residues of the

4 poultices (Feijoo et al 2013).

5 Moreover, when the rocks are affected by breakdown due to crystallization of salts, it is usual to

6 carry out a preconsolidation before the desalination treatment, using consolidants for that. This

7 preconsolidation slightly increases the cohesion of the rock, providing a safer handling during

8 the desalination treatment. However, preconsolidation also reduces the pore volume, reducing in

9 consequence the effectiveness of subsequent desalination technique (Lukaszewicz 1996a, 10 1996b). In this situation, it would be interesting to develop a desalination procedure which

11 allows an effective salt extraction without applying the devices directly in the sensitive area. By

12 this way, the risk of the loss of material derived from the direct contact with the desalination

13 devices would be eliminated, also avoiding a preconsolidation treatment.

14 Furthermore, the protruded carved areas (column capitals, archivolts, sculptures, etc., all of 15 them areas of a cultural high value) are usually more susceptible to the action of soluble salts.

16 This is due to the fact that, for the carving of these elements, a more porous rock is used,

17 helping the shaping of the surfaces. Also, due to its highlighted position on the monuments,

18 these areas are exposed to more intense weathering conditions and to a higher possibility of

19 drying and wetting cycles (so, crystallization and dissolution of salts). In the adjacent areas to

20 these sculpted elements, which are more protected and sheltered, the drying and wetting cycles

21 are less frequent and intense so, in them, the possibility of salt deterioration is lower.

Furthermore, in the protruded carved areas, remains of mural paintings are usually found, complicating the application of a desalination treatment directly on these areas. The application of any desalination treatment is accompanied by the use of water; this water can favour the chemical alteration of the pigments (Pel et al 2010) or the dissolution of the pigments especially when the treatment causes changes in the $\mathrm{pH}$ of the rock (Rörig-Dalgaard et al 2008). 
1 Recently, several researches confirmed that the desalination treatment based on eletrokinetic

2 principle are an effective method aimed to desalinate building surfaces by means the

3 establishment of an electric current between the electrodes positioned along the affected area

4 (Ottosen et al 2012; Rörig-Dalgaard 2013). These researches shown that the desalination takes

5 place in the areas where the electrodes are placed and also in the areas between them. However,

6 there is not any research focused on analysing the effectiveness of this desalination technique in

7 order to desalinate sculpted areas; the relief of these areas is an added difficulty for the

8 desalination process because the electric field established between the electrodes must to be

9 adapted to the shape of sculptural motif. Also, no studies exist about the evaluation of the

10 effectiveness of this technique to desalinate areas with a high salt content (and so, highly

11 deteriorated and usually affected by sand disaggregation) from adjacent areas with a low salt content.

13 This study is focused on evaluate a new desalination protocol, based on electrokinetic method,

14 designed in order to 1) desalinate areas highly affected by salts or areas with a high ion content

15 by placing the electrodes in another adjacent areas with a lesser salt content; 2) desalinate protruded surfaces or reliefs highly affected by salts by placing the electrodes outside these areas. For these purpose an ashlar of sandstone (in which a protruded area, highly contaminated by salts, was carved) was used in this experience. The electric field was applied by using

19 electrodes and electrolyte cells located in adjacent areas of the protruded area of the ashlar, which had lower ion content.

21 The results of this work could be an interesting contribution in the field of restoration of architectural and artistic cultural heritage affected by salts, when it is necessary to desalinate avoiding the direct contact between the desalination devices and the affected areas by salt

24 deterioration, in order to eliminate the risk of material loss, thus facilitating the preservation of 25 their historical and artistic value.

\section{Materials and Methods}

\subsection{Rock used}


1 For this study, a block of yellow sandstone extracted directly from the Kronborg Castle

2 (Denmark) was used. This fifteenth-century castle is located at the Oresund's Strait entrance,

3 guarding the entrance to the Baltic Sea in the Northwest of Zealand in Helsingør, Denmark.

4 This castle was declared World Cultural Heritage by UNESCO in 2000.

5 The proximity to the sea favours a high exposition to marine spray; in consequence, the rock, in

6 the building, shows the typical forms of deterioration associated with soluble salts: granular

7 disintegration, alveolar deterioration and superficial detachments. Furthermore, there are some

8 areas with black deposits which are associated to a fire occurred in 1629.

9 An ashlar of $28.8 \times 20.0 \times 28.8 \mathrm{~cm}$ of dimension was extracted from one of the outer walls of 10 the castle. A slab of $6.8 \mathrm{~cm}$ of thickness which comprises the exposed surface was cut from the 11 ashlar. On this slab, $3.1 \mathrm{~cm}$ into depth on each side of the central area was carved, in order to 12 create the protruded area (see Figure $1 \mathrm{a}-\mathrm{b}$ ). So, two areas have distinguished: the protruded area 13 (called in this research the central area) and the both sides of this central area, i.e., the adjacent 14 parts of the central area (called in this research neighbouring areas).

15 This recess, which evidently cannot be performed in situ, was carried out in order to increase the salt content only on the central area by capillary absorption. The aim of this contamination

17 (which is explained later) was to achieve an area with a high salt content (central area) 18 surrounded by an area with a lower salt content (neighbouring areas). This situation usually 19 occurs in monuments, where it is common to find areas such as reliefs, capital columns, archivolts or sculpted motifs with a higher salt content (in consequence with a degree of superficial decohesion that would make impossible the contact with the electrodes) and neighbouring areas with lower salt content (less deteriorated, where the desalination equipment could be placed).

\section{INSERT FIGURE 1}

During the carving process of the ashlar and before the salt contamination, four powder samples 
1 and stirred in $25 \mathrm{~mL}$ of ultrapure water during 24 hours. After filtration through $0.45 \mu \mathrm{m}$ filter,

2 the aqueous extract was analysed by high resolution chromatography (Dionex ICS-1100) in

3 order to obtain the anion content $\left(\mathrm{Cl}^{-}, \mathrm{NO}_{3}{ }^{-}\right.$and $\left.\mathrm{SO}_{4}{ }^{2-}\right)$ and the $\mathrm{pH}$ was measured using a $\mathrm{pH}-$

4 meter. In all the analyses performed in this study two replicas per sample were analysed.

5 From the back of this ashlar, samples were taken for the characterization of the rock. X-ray

6 fluorescence (Sequential X-ray Spectrometer Siemens SRS 3000), X-ray diffraction (Siemens

7 D5000 diffractometer) and SEM-EDX (Phillips XL 30) were applied in order to characterize the

8 sandstone from the chemical, mineralogical and textural points of view. Physical properties of

9 the rock were obtained following several standards. Open porosity, bulk and apparent density 10 were determined following RILEM (1980a) standard. Water absorption and desorption 11 coefficients were determined following the standards ICR-CNR (1981) and RILEM (1980b) 12 respectively. The capillary absorption kinetics and capillary absorption coefficient were 13 determined following the ICR-CNR (1985) standard. Finally, the mercury accessible porosity 14 and the pore size distribution of the rock were determined by mercury intrusion porosimetry, using a Micromeritics Autopore IV9500 porosimeter. This equipment uses two ranges of pressure, a low pressure range between $14 \mathrm{kPa}$ and $0.20 \mathrm{MPa}$, and a range of a high pressure between $0.20 \mathrm{MPa}$ and $225 \mathrm{MPa}$, which allowed to characterize a wide range of pore sizes from $100 \mu \mathrm{m}$ to $5 \mathrm{~nm}$.

\subsection{Contamination process with soluble salts}

In order to increase the soluble salt content of the rock only in the central area, a salt contamination process was carried out. For this purpose, the rock was wrapped with plastic film, leaving only the central area uncovered, as shown in Figure 1-a.

The central area of the sandstone was put into contact with a saline solution, composed of $9.9 \%$ $\mathrm{NaNO}_{3}, 6.6 \% \mathrm{NaCl}$, and $0.66 \% \mathrm{Ca}_{2} \mathrm{SO}_{4}$ in weight, favouring the absorption of the solution by capillary suction; this process lasted 2 days (see Fig. 1-c). After this time, the sandstone was taken out and dried for another 2 days at room temperature in a vertical position, allowing the salts which were absorbed to move and to accumulate only at the evaporation surface, i.e., in the 
1 central area. The plastic film which wrapped the neighbouring areas was used in order to favour

2 the evaporation towards the central area of the block.

3 A total of five cycles of contamination were conducted. Once the cycles of contamination were

4 ended, the block (still covered with plastic in the neighbouring areas) was left to dry at room

5 temperature during a week in order to promote the migration of the salts towards the central

6 area, and their accumulation in this area. Then, the plastic was removed and during another

7 week, the rock was left to dry at room temperature in order to favour the loss of the residual

8 moisture and to promote the crystallization of the salts, especially in areas where there is a

9 greater concentration of them. After this period of time, the central area of sandstone showed a

10 different aspect regarding to the initial appearance (see Fig. 1-d) due to the presence of the salts.

11 Before the application of the desalination treatment, a sampling in the central area (which was

12 contaminated, as indicated above) and in the neighbouring areas was performed in order to

13 determine the initial ionic content. Four reference samples were taken (see Fig. 2): two samples

14 covering the whole thickness of the protruded area $(31 \mathrm{~mm})$ were taken on the central area (right and left lower corners, B-C1 and B-C2 respectively) using a hammer and a chisel. Another two samples were extracted by drilling on the neighbouring areas, i.e. on each side of the central area (B-N1 and B-N2), covering the whole thickness of the ashlar in this areas (37 mm). All the samples extracted by hammer and chisel were divided in two sub-samples.

\section{INSERT FIGURE 2}

The samples were dried, crushed and homogenized. $10 \mathrm{~g}$ of each sample were stirred in $25 \mathrm{~mL}$ of ultrapure water during 24 hours. After filtration through $0.45 \mu \mathrm{m}$ filter, the anion content $\left(\mathrm{Cl}^{-}\right.$, $\mathrm{NO}_{3}{ }^{-}$and $\mathrm{SO}_{4}{ }^{2-}$ ) was obtained by means high resolution chromatography (Dionex ICS-1100) and the $\mathrm{pH}$ was measured using a $\mathrm{pH}$-meter. Two replicas per sample were analysed.

\subsection{Desalination procedure. Setup}

The laboratory setup is described in Fig. 3. In this setup, two rows of electrodes were applied in 
1 had two electrolytic cells (with external and internal diameters of $6 \mathrm{~cm}$ and $4 \mathrm{~cm}$ respectively)

2 located all at a distance of $2 \mathrm{~cm}$ from the edges of the ashlar. The anodes were placed on the left

3 side and the cathodes were placed on the right side. Four cylindrical titanium bars inserted into

4 the poultices were used as electrodes.

\section{INSERT FIGURE 3}

6 As electrolyte, a solution of $0.2 \mathrm{M}$ sodium citrate and $0.2 \mathrm{M}$ citric acid buffered to $\mathrm{pH} 6$ was

7 used. The suitability of this electrolyte in favouring the salt extraction and also in buffering the

$8 \mathrm{pH}$ variations caused by the hydrolysis of water (reactions 1 and 5) was demonstrated in

9 previous works (Feijoo et al 2013, 2015).

10 All the cells were filled with a poultice in order to retain the ions mobilized by the electric field.

11 In the anode cells, the poultices were made of kaolin: $\mathrm{CaCO}_{3}$ :buffer electrolyte in a proportion of

$12 \quad 1: 2: 1.3$ by weight. In the cathode, the poultices were made of kaolin and buffer electrolyte in a

13 proportion of $1.6: 1$ by weight. $\mathrm{CaCO}_{3}$ and kaolin were used in order to strength the buffering

14 capacity of the electrolyte by means the following reactions.

15 The reactions taking place at the anode are:

$16 \quad \mathrm{H}_{2} \mathrm{O} \rightarrow 2 \mathrm{H}^{+}+1 / 2 \mathrm{O}_{2(\mathrm{~g})}+2 \mathrm{e}^{-} \quad \mathrm{Re}-[1]$

$17 \quad 2 \mathrm{Cl}^{-} \rightarrow \mathrm{Cl}_{2(\mathrm{~g})}+2 \mathrm{e}^{-} \quad$ Re-[2]

18 The $\mathrm{CaCO}_{3}$ present in the anode cell decomposes at acidic $\mathrm{pH}$ (reactions 3 and 4) buffering the

19 hydrogen ions due to the hydrolysis of water (reaction 1). The effectiveness of the use of $\mathrm{CaCO}_{3}$

20 in the anode cell to buffer $\mathrm{pH}$ variations has been demonstrated in other studies (Feijoo et al

21 2013, 2015; Ottosen 2010; Rörig-Dalgaard 2013).

22 So, the buffering processes at the anolyte are:

$\mathrm{CaCO}_{3}+\mathrm{H}^{+} \rightarrow \mathrm{Ca}^{2+}+\mathrm{HCO}_{3}^{-}$

$\operatorname{Re}-[3]$

$24 \mathrm{HCO}_{3}{ }^{-}+\mathrm{H}^{+} \rightarrow \mathrm{CO}_{2(\mathrm{~g})}+\mathrm{H}_{2} \mathrm{O}$

Re-[4]

25 On the other hand, the main cathodic reaction is: 


$$
1 \quad 2 \mathrm{H}_{2} \mathrm{O}+2 \mathrm{e}^{-} \rightarrow 2 \mathrm{OH}^{-}+\mathrm{H}_{2(\mathrm{~g})} \quad \text { Re-[5] }
$$

2 The added kaolin at the cathode cells acts as colloid with capacity to buffer and to retain the

$3 \mathrm{OH}^{-}$ions generated at the cathode (reaction 5), preventing that the corresponding $\mathrm{pH}$ increase

4 affects the treated material and hindering the entrance of this ion into the rock (Feijoo et al 5 2013, 2015). So, by avoiding the entrance of $\mathrm{OH}^{-}$, which has a greater mobility than the other

6 ions, the transference number (i.e., the part of the electric current carried by a specific ion) and

7 in consequence the extraction efficiency of the other anions present into the rock would be 8 increased (Castellote et al 2000) (Ottosen et al 2007, 2008, 2009, 2010).

9 In order to reduce the possible colour changes on the rock caused by the contact with the 10 poultices of the electrolytic cells, a piece of a silk paper was inserted between the rock and the 11 poultices. This arrangement is often recommended for the desalination treatments by the 12 application of poultices (Auras 2008).

13 Regarding the electrical system, $15 \mathrm{~V}$ constant potential was applied in each row of the 14 electrodes. Each row of electrodes (upper and lower) was connected in series with a $1 \mathrm{k} \Omega$ resistor which allowed to measure the current flow through each row using Ohm's law.

16 In addition, to ensure the same potential for the cathodes, a short-circuit was established with 17 the grounding of one of the power supplies used.

18 The test consisted of periodic irrigation cycles of the rock with electrolyte (to dissolve salts and 19 to allow the ionic mobilization) alternated with electrokinetic desalination cycles. With this 20 purpose, it was necessary to use two timers, one for switch on/off the irrigation system and 21 another one to switch on/off the electric current for the desalination. The irrigation system consisted on a pump connected to 7 droppers located over the sample, three above the central 23 area and two on each side (see Fig. 3). One of the timers (timer 1) switches on the pump which 24 feeds the irrigation system during 15 min every three hours, producing a flux to the rock of 4.4 $25.10^{-5} \mathrm{~L} / \mathrm{s}$ of electrolyte. This amount of electrolyte flow was considered enough to moistening 26 the sample and dissolving the salts. 
1 After the 15 minutes of irrigation, the timer 1 switched off the irrigation system and the other

2 (timer 2) switched on two power supplies, providing a flow of a direct current for 3 hours.

3 Furthermore, $10 \mathrm{~mL}$ of electrolyte was added into each cell every day in order to slow down the

4 drying process of the poultices, mainly the poultices located at the anode.

\section{$5 \quad$ 2.4. Desalination treatment monitoring}

6 In order to obtain information about the ionic mobilization and the moisture content of the

7 poultices, measurements of intensity and resistance between the electrodes of each row were

8 conducted during the desalination treatment using a digital multimeter. Each day, 8

9 measurements were taken.

10 The poultices were renewed each 5 days and analysed in order to know the amount of anions

11 removed. For this, each poultice was left to dry at $50^{\circ} \mathrm{C}$ during 4 days and after that, the poultice

12 was weighed, crushed by hand and homogenized and finally were taken four aliquots of $10 \mathrm{~g}$

13 each one. Each aliquot was stirred in $25 \mathrm{~mL}$ of ultrapure water during 24 hours. After filtration

14 through $0.45 \mu \mathrm{m}$ filter, the $\mathrm{pH}$ was measured using a $\mathrm{pH}$-meter and the anions were analysed by high resolution chromatography. The $\mathrm{pH}$ measurement gives information about the $\mathrm{pH}$ of the environment under which the stone is being desalinated. The ionic content analysis provides an idea of the effectiveness of the desalination process and also of the moment at which the treatment can be considered finished, which corresponds to the time at which the extractions achieved at the anode are similar to those achieved at the cathode and, in both cases, close to zero (Feijoo et al 2015).

21 After 25 days (after five poultices renewal), the test was ended regardless of intensity and resistance measurements and the ionic content extracted in each of the poultices. In this way it is possible to carry out an analysis of the effectiveness of the treatment against the extraction of

24 the different anions which are present in the material and which have a different mobility. At this moment, the ionic content remained on the rock was analysed. For this, the stone was left to dry at a room temperature during one week and after that, different samples were taken in order 
1 to carry out the analysis. Seven samples were taken from the central area (see Fig. 3): three

3 to a depth corresponding to the entire thickness $(68 \mathrm{~mm})$ and four samples were taken on the corners (samples A-C4 to A-C7) using a hammer and a chisel to a depth of $31 \mathrm{~mm}$. Another six samples more were taken on the neighbouring areas by drilling to a depth corresponding to the entire thickness of this area $(37 \mathrm{~mm})$ : four of the samples were taken in the same places in which the electrolytic cells with the electrodes were placed (samples A-N1 and A-N2 on the anodic area and A-N4 and A-N5 on the cathodic area) and the other two samples were taken in an intermediate position between the electrolytic cells (samples A-N3 and A-N6). After drying, crushing and homogenization of the samples, $10 \mathrm{~g}$ of each sample were stirred in $25 \mathrm{~mL}$ of ultrapure water during 24 hours and filtered through a filter of $0.45 \mu \mathrm{m}$. In the aqueous extract obtained, $\mathrm{pH}$ was measured using a $\mathrm{pH}$-meter and the anions were analysed by high resolution chromatography.

To evaluate the effectiveness of the treatment, the ratio between the concentration of each ion after the desalination with respect to the concentration of the same ion before desalination, for each sample, was calculated according to (Lubelli et al 2011), expressed in \% and referring in this work as E-\% [ion].

The effectiveness of the desalination treatment was also evaluated by means the Austrian standard Önorm B 3355-1 (2006). This standard, also used in (Ottosen et al 2007, 2008), provides guidelines for evaluation whether the ion content in a building involves a risk due to crystallization (values of concentration above the limit established by this standard), and if it is necessary or advisable to carry out an intervention (concentration between the two limits). For the main anions, these limits are (critical limit - limit for no risk): $\mathrm{Cl}^{-}(1000 \mathrm{mg} / \mathrm{kg}-300 \mathrm{mg}$ / $\mathrm{kg}), \mathrm{NO}_{3}^{-}(1500 \mathrm{mg} / \mathrm{kg}-500 \mathrm{mg} / \mathrm{kg}), \mathrm{SO}_{4}{ }^{2-}(2500 \mathrm{mg} / \mathrm{kg}-1000 \mathrm{mg} / \mathrm{kg})$.

\section{Results and Discussion}

\subsection{Rock characterization and initial ion content}


1 The main minerals of the rock, identified by X-ray diffraction, are quartz and kaolinite. The

$3 \mathrm{SiO}_{2}(95.07 \%), \mathrm{Al}_{2} \mathrm{O}_{3}(3.26 \%), \mathrm{CaO}(0.418 \%), \mathrm{TiO}_{2}(0.323 \%), \mathrm{K}_{2} \mathrm{O}(0.203 \%), \mathrm{Fe}_{2} \mathrm{O}_{3}(0.177 \%)$

4 and $\mathrm{Na}_{2} \mathrm{O}(0.15 \%)$; as minor components, $\mathrm{ZrO}_{2}(0.0855 \%), \mathrm{SO}_{3}(0.067 \%), \mathrm{MgO}(0.057 \%)$ and

$5 \mathrm{Rb}_{2} \mathrm{O}(0.0438)$ were identified. Petrographically, the rock is a very fine grained sandstone,

6 composed by subangular quartz grains $(50-100 \mu \mathrm{m})$ cemented by kaolinite plates.

7 Table 1 shows the physical properties of the sandstone. The porosity values and the parameters

8 related to the water absorption suggest a great connectivity between the pores involved in the

9 water transport processes, which would be positive in enhancing the desalination processes.

10 The initial ion content (before the contamination cycles with salts) expressed in $\mathrm{mg}$ per $\mathrm{kg}$ of

11 rock of the sandstone was $\mathrm{Cl}^{-}: 32 \pm 0.14 ; \mathrm{NO}_{3}^{-}: 5.5 \pm 0.04$ and $\mathrm{SO}_{4}^{2-}: 17 \pm 3.00$.

12 INSERT TABLE 1

13 The pore size distribution obtained by mercury intrusion porosimetry reveals that this sandstone 14 has a bimodal pore size distribution with pores with a pore size diameter between 0.1 and $10 \mu \mathrm{m}$ and pores with a pore size diameter greater than $100 \mu \mathrm{m}$. About $74 \%$ of the total porosity is defined by pores of diameter in the range of $0.1-10 \mu \mathrm{m}$. The $88 \%$ of the pore volume corresponds to pores of pore size diameter between 0.1-100 $\mu \mathrm{m}$, i.e., pores of capillary absorption (Winkler 1997). Only a small fraction of the total porosity (about 5\%) lies in the nano-meter range.

Before the desalination test, the anion content of the samples taken in the central area and in the neighbouring areas is shown in Table 2: the anionic content in the central area was almost one order of magnitude higher than the ion content of the neighbouring areas, except in the case of the sulphate which was two orders of magnitude higher. This ion content in the central area of

24 the sandstone overcame the upper limit proposed by the Austrian norm Önorm B 3355-1 (2006), which justifies a desalination intervention. 
1 In the neighbouring areas, the anionic content is significantly lower than that of the central area

2 of the sandstone. So, the salt contamination procedure was effectively in achieve a stone piece

3 suitable for carry out the desalination test which intends desalinate the central area (with a

4 higher content of salts) from areas less affected by soluble salts with a lower ion content

5 (neighbouring areas). In the neighbouring areas, the concentration of chlorides and nitrates

6 exceeded the upper limits given by the Austrian norm Önorm B 3355-1 (2006) which is not the

7 case of sulphate, which appears in low amounts.

8 Two reasons could explain the higher ion content present in the neighbouring areas of the block

9 with respect to the initial ion content (i.e., before the contamination cycles): I) a possible migration of the more mobile ions from the central area to the neighbouring areas of the block.

11 In this sense, it is necessary take into account that the plastic that covered the block was

12 removed 7 days after the ended of the contamination cycles. In that moment it was possible to

13 appreciate throughout the piece some residual moisture that could be the cause of the movement

14 of ions from the central area to the neighbouring areas; II) according to (Pel et al 2003) the

15 movement of the dissolved salts during the first stages of drying is due to an advective process,

16 which tends to mobilize the dissolved salts towards the evaporation surface, in which they

17 crystallize. This could has occurred during the contamination of the central area of the block.

18 On the other hand, the same authors also state that the movement of the dissolved salts during

19 the last stages of drying, is produced by diffusive processes; this could explain that, regardless

20 of the plastic removal, a mobilization of ions would occur towards the neighbouring areas.

\section{$21 \quad 3.2 . \quad$ Desalination test monitoring}

The current intensity and resistance measurements taken during the desalation test are depicted in Figure 4. A similar tendency in the variation of these parameters in the two rows of electrodes (upper and lower) was observed. At each poultice application, a sudden increase on

25 the current intensity (and the consequent drop on resistance) was observed, followed by a drop on the current intensity (and therefore, an increase in resistance). These variations are related 
1 with the variations in the moisture content on the sandstone block and on the poultices due to

3

4

5

6

7 the daily addiction of the electrolyte.

\section{INSERT FIGURE 4}

Despite these variations, it can be seen that the current intensity and resistance data oscillated in a constant range (between 2 to $8 \mathrm{~mA}$ and between 1 to $6 \mathrm{k} \Omega$ with some exception). This fact could indicate that the desalination process seemed to progress slowly or even it was still occurring at the time of completion of the test; otherwise, resistance measurements would have increased significantly as the ion content in the rock was being reduced, as reflected in previous works (Arya and Sa'id-Shawqi 1996; Díaz et al 2014; Feijoo et al 2013, 2015; Koleva et al 2008; Ottosen and Rörig-Dalgaard 2009).

Despite this fact, the analyses of the ion content in the poultices after each application revealed that a noticeable reduction of the ion content took place. Figure 5 shows the anionic content (chlorides, nitrates and sulphates) in each of the poultices after each application and also the total content removed, calculated as the sum of the ion content removed in each poultice application. Values correspond to the average of the four samples of each poultice (see section 2.4). In all the cases the standard deviation is also represented.

From Figure 5-a, a significant removal of chloride at the anode was deduced, reaching a total extraction values (sum of the five applications) between 2000 and $5000 \mathrm{mg} / \mathrm{kg}$. The chloride content removed was, as expected, higher in the anode poultices than in the cathode poultices (electromigration process).

Also, chloride extraction was higher in the lower row of electrodes; this occurred throughout all the test, except after the last application of poultices, when the content of chloride removed is drastically reduced. This could be due to the irrigation process: when the irrigation system is switched on, the chloride ions could be dragged by the electrolyte from the upper part of the ashlar towards the bottom part due to a gravitational transport through the large size pores; this could explain the higher removal of chloride in the lower row. 
1 In the anode placed at the upper row, an increasing tendency of chloride removal is found,

2 indicating that the extraction process of this ion would continue in this area of the ashlar if the

3 desalation test had been extended longer.

\section{INSERT FIGURE 5}

5 The extraction of nitrate (Fig. 5-b) was also higher in the anodes than in the cathodes except at

6 the last poultice application. The pattern of the removal of this ion was similar to the chloride

7 pattern: 1) the extraction was higher in the lower row of electrodes than in the upper row of

8 electrodes; and 2) in the lower row of electrodes, the content of extracted nitrate decreased at

9 the fifth application of the poultice; this decrease was not observed in the upper row of

10 electrodes which seems to suggest that the treatment, in this level, should have been extended

11 longer. It was also found that the total content of extracted nitrate was much higher than the

12 total content of extracted chloride, reaching a total removed nitrate content of $65000 \mathrm{mg} / \mathrm{kg}$

13 approximately; this result was expected owing the higher concentration of this ion in the ashlar

14 before the treatment (Table 2).

15 It is also shown that, in the fifth poultice application, the amount of extracted nitrate in the cathodic compartments increased, which could indicate the possible formation of chemical complexes that change the anion charge which, in turn, would cause a change of the direction of

18 ion migration; in this sense, other authors reported the formation $\mathrm{Ca}\left(\mathrm{NO}_{3}\right)^{+}(\mathrm{Paz}$ García et al 19 2012, 2013). This fact could explain the drastic drop in the removed amount of nitrate which occurred in the anode located in the lower row.

21 The total amount of extracted sulphate (see Fig. 5-c) was lower in comparison with the other anions. The difference between the sulphate content removed in the anodic compartment and the content removed in the cathodic compartment was low, contrary to what happened with the

24 chloride and nitrate extraction. This fact suggests that the relevance of the sulphate ion in the current transport would be low, which would support that the removal process of this anion involves other mechanisms of transport such as advection and diffusion. 
1 If a comparison among the total ion content is made (see Fig. 5), it is possible to see that the

2 total amounts of chloride and nitrate removed were much higher in the anode compartments;

3 this was the expected behaviour according to the charge of these ions. The presence of certain

4 content of these anions in the cathode compartments could be related to diffusion and advection

5 processes or to the possible formation of chemical complex with inverted charge (Paz García et

6 al 2012, 2013).

7 Regarding sulphate ion, its ability to be mobilized under electric current seems to be different to

8 that of chloride and nitrate anions, since the amount of sulphate removed in the anode and the

9 cathode was similar. The reason for this is probably related to the ion mobility. The more

10 mobile ions under electric current are the mainly responsible for the current transport as indicate

11 in (Castellote et al 2000) (Ottosen et al 2007, 2008, 2009, 2010) (Rörig-Dalgaard 2013). So, when the mobile ions (in this case, chloride and nitrate) are present in the porous medium in a

13 very high concentration, the transport of sulphates is produced mainly 1) associated to the

14 advection movement of the water towards the evaporation surfaces and also 2) by diffusion

15 from the areas with a high concentration towards the neighbouring areas with a low concentration; both transport mechanisms have certain impact in the transport of chemical species as indicated in the Nerst-Plack equation (Paz García et al 2012). Another possible sulphate transport could be associated with the movement of water molecules by electroosmotic

19 flow which should occur from the anode to the cathode, since the inner surface of this sandstone 20 is negatively charged (zeta potential $=-24 \mathrm{mV}$ ). However different studies have shown that the 21 electroosmotic process is null when the ion content inside the material is high (Bertolini et al 2009) (Ottosen and Rörig-Dalgaard 2006).

This hypothesis is supported with the results of the analysis of the last poultice application and also with other previous experiences (Castellote et al 2000) (Ottosen et al 2007, 2008, 2009, 2010). In the fifth application, an increase in the removal of sulphate in the lower anode it was observed, together with a decrease in the removal of chloride and nitrate. The reduction in the amount of chloride and nitrate inside the stone in this last stage of the test could have favoured 
1 an increase in the electric current transport by the less mobile ion (sulphate) and in consequence

2 in the rate of its removal.

3 The $\mathrm{pH}$ measurements performed in the poultices at each application and also in the aqueous

4 extracts of rock samples showed that significant changes in $\mathrm{pH}$ have not occurred during the

5 treatment. The $\mathrm{pH}$ in the poultices remained nearly neutral in the anode compartments where the

6 values of $\mathrm{pH}$ remained on $7.30 \pm 0.35$; in the cathode, $\mathrm{pH}$ values of $10.50 \pm 0.75$ were recorded.

7 However in the aqueous extracts of rock samples the $\mathrm{pH}$ has not showed high variations with

8 respect to the initial $\mathrm{pH}(6.90 \pm 0.20)$, showing values of $7.45 \pm 0.34$. These values demonstrate,

9 as in other studies (Feijoo et al 2013, 2015; Ottosen et al 2010; Rörig-Dalgaard 2013), that the

10 choice of the electrolyte and the use of calcium carbonate were effective in order to buffer the

11 extreme decrease of $\mathrm{pH}$ to be expected in the vicinity of the anodes. In the cathodes, despite the

12 basic $\mathrm{pH}$ reached in poultices, it appears that the use of kaolin to buffer the $\mathrm{OH}^{-}$produced by the

13 hydrolysis of water, was sufficiently effective, since the $\mathrm{pH}$ of the aqueous rock extracts was

14 maintained near the neutrality.

\subsection{Desalination effectiveness}

Table 2 shows the final ion content of the samples taken from the central area and from the neighbouring areas of the ashlar after the desalination treatment. In the central area of the rock there has been a considerable decrease in the ionic content, especially in the case of chloride and nitrate ions, as reflected in the reduction percentages which exceed in all the cases the $80 \%$. These reduction percentages were higher in the areas closest to the cathode, which is logical taking into account their negative charge and their mobilization towards the anode which promote a greater accumulation of these ions in the anodic area of the sandstone block.

In the case of the sulphate content, the percentages of the removal were not so high; in one case (sample A-C5), it was even negative. This indicates that a sulphate enrichment has took place. Furthermore and as opposed what happened with the other two anions, the reduction percentages were higher in the anode area. This results are in concordance with the sulphate content removed by the poultices (see section 3.2): so, the similar extraction levels attained by 
1 the poultices in both the anode and the cathode, could indicate that sulphate ion (less mobile)

2 has not been extracted as easily as the other two (chloride and nitrate) by means the application

3 of electric current, suggesting the implication of another mechanisms in its mobilization and

4 subsequent extraction.

5 In the neighbouring areas (Table 2), a notable decrease of chloride and nitrate ions has also been

6 produced. It can be seen again that, after desalination, the chloride and nitrate amounts were

7 higher in the anodic area than in the catodic area (45-60\% of chloride and $68-84 \%$ of nitrate in

8 the anode area and close to $90 \%$ for both ions in the cathode area), demonstrating that an

9 anionic movement really took place. Nevertheless, the existence of variable amounts of these

10 anions in the cathodes could indicate 1) an incomplete desalination, 2) the mobilization of a

11 little amount of this ion towards the cathode by advection or diffusion processes and/or 3) the

12 formation of cationic complexes of $\mathrm{Cl}^{-}$and $\mathrm{NO}_{3}{ }^{-}$which migrate towards the cathode (Paz García

13 et al 2012, 2013).

14 Also in the neighbouring areas, the negative percentage of sulphate reduction could indicate that an enrichment of this anion has been produced in these areas, being the final content of sulphate in the rock higher in the area of the cathode. These results would also suggest that 1) the influence of the sulphate ion in the transport of the electric current through the pores of the stone was low, probably due to the presence of a high ionic content of ions with higher mobility such as chloride and nitrate; 2) the movement of sulphate was produced mainly by other mechanisms such as the advection and diffusion, at least until the time at which the contents of chloride and nitrate was reduced (fifth application in the lower row).

Despite the observed enrichments in this area of the rock, the final content of sulphate in all the cases were lower to the risk limit set by the Austrian standard Önorm (2006).

In general terms, it was shown that the desalination treatment allowed reducing the high ionic content of the rock. However, the final ionic content obtained (Table 2) represents a serious risk following the Austrian Önorm B 3355-1 (2006), especially regarding nitrates. These results would suggest that the treatment should have been extended longer; the final ion content in the 
1 rock would be high enough to guarantee the transport of the electrical current if the treatment

2 had not been interrupted; the resistance data (see Fig. 4) support this idea, because no significant

3 increase in this parameter was observed. Also the progressive increase of extracted ions in the

4 poultices after each application would indicate that the desalination process was stopped ahead

5 of time.

6 Regarding to the aesthetic parameter, the visual appearance of the sandstone at the end of the

7 treatment was similar to the initial appearance of this stone without salts (see Fig. 1 and 6).

\section{INSERT FIGURE 6}

\section{4. Conclusions}

10 From the obtained results, the following conclusions can be stablished.

11 The high reduction of the nitrate and chloride content in the central area, by means the 12 establishment of an electric current out of these areas (neighbouring areas) confirmed that the 13 desalination setup proposed was effective to extract these salts without putting the electrodes in 14 direct contact with the affected area. Therefore, this procedure could be applied to desalinate stones affected by the deterioration forms related to soluble salts (sand disaggregation or superficial detachments), allowing to reduce the risk of loss of the material as a result of the

17 placement of electrodes directly on these areas. The results also show that it is possible to carry

18 out this treatment without causing increases of the ionic content on the neighbouring areas

19 where the electrodes are placed, at least with respect to the chloride and nitrate. So, these results confirm the suitability of this electrokinetic desalination setup to remove the salts on protruded carved areas, on which the electrodes are difficult to place due to the relief of the surfaces.

Nevertheless, the procedure was not as effective for removing sulphate; the results indicate that an increase in the duration of the treatment would have allowed to conveniently reduce the sulphate content. A longer time would allow to decrease the content of the more mobile ions (chloride and nitrate) and, in consequence, to increase the amount of electric current transported by the sulphate, thus facilitating its extraction. 
1 The resistance measurements during the test and the ion content of the poultices also shown that

2 the process was ended prematurely: the treatment was stopped when the mobilization of the

3 anions towards the poultices was still taking place, which explain the increase of sulphate on the

4 neighbouring areas where the electrodes were placed. Also, the final salt content remained in the

5 stone was higher (especially for nitrates) in relation to the Austrian Norm.

6 Despite these facts, the desalination procedure proposed avoids the exposure of the rock at 7 extreme $\mathrm{pH}$ changes; the $\mathrm{pH}$ data confirmed that, using the electrolyte proposed and also

8 calcium carbonate and kaolin in the poultices, it was possible to use the electrokinetic

9 techniques in the desalination of rocks without risk due to $\mathrm{pH}$ changes.

10 So in view of the results obtained and as a main conclusion, it was demonstrated the possibility

11 of an effective application of this electrokinetic desalination treatment without direct contact

12 with the affected surfaces. This procedure would allow to redesign the future intervention

13 campaigns on monuments, buildings or porous materials in general that are affected by soluble

14 salts.

\section{Acknowledgements}

16 This work was supported by the project CTM2010-19584 funded by Ministerio de Ciencia y

17 Tecnología from Spanish Government 2010. J. Feijoo work is supported by the Ministerio de 18 Educación, Cultura y Deporte, Spanish Government, through a FPU grant. The analyses of IC 19 were performed in the Department of Civil Engineering (BYG) from the Technical University 20 of Denmark (DTU) and the pore size distribution was performed in the Department of Chemical 21 Engineering (Encomat group) from the University of Vigo. 


\section{References}

2 Arya. C.; Sa'id-Shawqi. Q. Factors influencing electrochemical removal of chloride from

3 concrete. Cement and concrete research. 1996 Vol. 26 nº 6. pp. 851-860.

4 Auras, M. Poultices and mortars for salt contaminated masonry an stone objects. Proc.

5 International Conference Salt weathering on buildings and stone sculptures. 22-24 October

6 2008. The National Museum Copenhagen, Denmark. Technical University of Denmark.

7 Bertolini, L.; Coppola, L.; Gastaldi, M.; Redaelli, E. Electroosmotic transport in porous 8 construction materials and dehumidification of masonry. Construction and Buildind Materials $9 \quad 2009 ; 23: 254-263$

10 Cardell, C., Delalieux, F., Roumpopoulos, K., Moropoulous, A., Auger, F., Van Greeken, R.

11 Salt-induced decay in calcareous stone monuments and buildings in a marine environment in

12 SW France. Construction and Building Materials 2003; 17:165-179.

13 Castellote, M.; Andrade, C.; Alonso, C. Electrochemical removal of chlorides. Modelling of 14 extraction, resulting profiles and determination of the efficient time of treatment. Cement and 15 Concrete Research 2000; 30:615-621.

16 Charola, A.E. Salts in the deterioration of porous materials. An overview. Journal of American 17 Institute for Conservation 2000; 39: 327-343.

18 Charola A.E.; Pühringer J.; Steiger M. Gypsum: a review of its role in the deterioration of 19 building materials. Environmental Geology 2007; 52:339-352.

20 Díaz, B., Nóvoa, X.R., Puga, B., Vivier, V. 2014. Macro and micro aspects of the transport of 21 chlorides in cementitious membranes. Electrochimica Acta 124, pp. 61-68.

22 Feijoo J, Novoa XR, Rivas T, Mosquera MJ, Taboada J, Montojo C, et al. Granite desalination 23 using electromigration. Influence of type of granite and saline contaminant. Journal of Cultural 24 Heritage 2013; 14: 365-376. 
1 Feijoo, J.; Ottosen, L.M.; Pozo-Antonio, I. Influence of the properties of granite and sandstone

2 in the desalination process by electrokinetic technique. Electrochimica Acta 2015; 181: 280287.

4 Honeyborne D.B. Weathering and decay of masonry. In Conservation of building and

5 decorative stone. Paperback ed. edited by John Ashurst and Francis G. Dimes, 1998; 153-84.

6 Oxford ; Woburn, Mass.: Butterworth-Heinemann.

7 ICR-CNR-Instituto Centrale do Restauro-Commisione Normal. 1981. Doc. NORMAL 7/81.

8 Assorbimentod'acqua per immersionetotale. Capacitá di imbibizione.

9 ICR-CNR- Instituto Centrale do restauro- Commisione Normal. 1985. Doc. NORMAL 11/85.

10 Assorbimentod'acqua per capilaritá. Coefficiente di assorbimento capillare.

11 Koleva, D.A.; Copuroglu, O.; Van Breugel, K.; Ye, G.; de Wit, J.H.W. Electrical resistivity and 12 microstructural properties of concrete materials in conditions of current flow. Cement and 13 Concrete Composites 2008; 30:731-744.

14 La Iglesia A.; González V.; López-Acevedo; Viedma C. Salt crystallization in porous construction materials I. Estimation of crystallization pressure. Journal of Crystal Growth 1997; 16 177: 111-118.

17 Lubelli, B.; van Hees, R.P.J. Effectiveness of crystallization inhibitors in preventing salt 18 damage in building materials”. Journal of Cultural Heritage 2007; 8: 223-234.

19 Lubelli, B.; van Hees, R.P.J. Desalination of masonry structures: Fine tuning of pore size distribution of poultices to substrate properties". Journal of Cultural Heritage 2010; 11:10-18.

21 Lubelli, B.; Van Hess, R.P.J.; De Clercq, H. Fine tuning of desalination poultices; try-outs in 22 practice SWBSS 2011. Limassol. Cypruss.

Lukaszewicz, J.W. The influence of stone preconsolidation with ethyl silicate on soluble salts removal. In Proceedings of the Eighth International Conference on Deterioration and 1209. 
1 Lukaszewicz, J.W. The influence of stone preconsolidation with ethyl silicate on deep

2 consolidation. In Proceedings of the Eighth International Conference on Deterioration and

3 conservation of Stone: Berlin, 30 September-4 October 1996b, ed. Joseph Riederer, pp. 1209-

41215.

5 ÖNOR.M.B. 3355-1, Trockenlegung von feuchtemMauerwerk - Teil 1: Bauwerksdiagnose und

6 Planungsgrundlagen Berlin. ASI Austrian Standards Institute ÖsterreichischesNormungsinstitut

7 (Herausgeber) Deutschland, Bundesrepublik, BeuthVerlag, 2006.

8 Ottosen, L.M.; Rörig-Dalgaard, I. Drying brick masonry by electro-osmosis. Proceedings from

$9 \quad 7^{\text {th }}$ International Masonry Conference, London, UK, 2006, 31-41.

10 Ottosen, L.M.; Rörig-Dalgaard, I. Electrokinetic removal of $\mathrm{Ca}\left(\mathrm{NO}_{3}\right)_{2}$ from bricks to avoid salt11 induced decay, Electrochimica Acta 2007; 52:3454-3463.

12 Ottosen, L.M.; Pedersen, A.J.; Rörig-Dalgaard, I. Salt-related problems in brick masonry and 13 electrokinetic removal of salts. Journal of Building Appraisal 2007 Vol 3 no.3 pp 181-194.

14 Ottosen, L.M.; Christensen, I.V.; Rörig-Dalgaard, I.; Pernille-Jensen, E.; Hansen H.K.

15 Utilization of electromigration in civil and environmental engineering-Processes, transport 16 rates and matrix changes, Journal of Environmental Science and Health, Part A: 17 Toxic/Hazardous Substances and Environmental Engineering 2008; 43:8, 795-809.

18 Ottosen, L.M.; Rörig-Dalgaard, I. Desalination of a brick by application of an electric DC field.

19 Materials and Structures 2009; 42:961-971.

20 Ottosen L.M.; Ferreira C.M.D.; Christensen I.V. Electrokinetic desalination of glazed ceramic 21 tiles. J Appl. Electrochem 2010; 40:1161-1171.

22 Ottosen, L.M., Christensen, I.V.; Rörig-Dalgaard, I. Electrochemical desalination of salt 23 infected limestone masonry of a historic warehouse. Structural Faults and Repair, Edinburgh 2012. 
1 Paz García, J.M.; Johannesson, B.; Ottosen, L.M.; Alshawabkeh, A.N.; Ribeiro, A.B.;

2 Rodríguez-Maroto, J.M. Modeling of electrokinetic desalination of bricks. Electrochimica Acta 2012; 86: 213-222.

4 Paz García, J.M.; Johannesson, B.; Ottosen, L.M.; Ribeiro, A.B.; Rodríguez-Maroto, J.M.

5 Simulation-based analysis of the differences in the removal rate of chlorides, nitrates and

6 sulfates by electrokinetic desalination treatments. Electrochimica Acta 2013; 89: 436-444.

7 Pel, L.; Huinink, H.; Kopinga, K. Salt transport and crystallization in porous building materials,

8 Magnetic Resonance Imaging 2003; 21: 317-320.

9 Pel, L.; Sawdy, A.; Voronina, V. Physical principles and efficiency of salt extraction by 10 poulticing. Journal of Cultural Heritage 11 (2010) 59-67.

11 RILEM (RéunionInternationale des Laboratoiresd'Essaiset de Recherchesur les Matériauxet les 12 Constructions). Commission 25 PEM. Protection et Erosion des Monuments. 13 Recommandationsprovisoires. Essaisrecommandés pour mesurerl'altération des pierres et 14 évaluerl'efficacité des méthodes de traitement. Test No. II. 1: Open porosity and Test II. 2: Bulk and real densities. (1980a).

16 RILEM- RéunionInternationale des Laboratoiresd'Essaiset de Recherchesur les Matériauxet les 17 Constructions. 1980b. Commission 25 PEM. Protection et Erosion des Monuments. 18 Recommandationsprovisoires. Essaisrecommandés pour mesurerl'altération de pierres et 19 évaluerl'efficacité des méthodes de traitement. Test n ${ }^{\circ} 11.5$, Evaporation curve.

20 Rivas, T.; Alvarez, E.; Mosquera, M.J.; Alejano, L.; Taboada, J. Crystallization modifiers 21 applied in granite desalination: The role of the Stone pore structure. Construction and Building 22 Materials 2010; 24: 766-776.

23 Rörig-Dalgaard, I. Development of a poultice for electrochemical desalination of porous 24 building materials: desalination effect and pH changes. Materials and Structures 2013; 46:959970. 
1 Rörig-Dalgaard I.; Ottosen, L.M.; Christensen, I.V. Desalination of a wall section with murals

2 by electromigration. Proc. International Conference Salt weathering on buildings and stone

3 sculptures. 22-24 October 2008. The National Museum Copenhagen, Denmark. Technical

4 University of Denmark, pp. 361-371

5 Setina, J.; Kirilova, S. Clay Based Poultices for Desalination of Building Materials. Journal of

6 sustainable architecture and civil engineering 2012 ISSN 2029-9990

7 Steiger M. Crystal growth in porous materials- I: The crystallization pressure of large crystals.

8 Journal of Crystal Growth 2005; 282: 455-469.

9 Tsui, N.; Flatt, R.J.; Scherer, G.W. Crystallization damage by sodium sulfate. Journal of

10 Cultural heritage 2003; 4:109-115.

11 Unhruh, J. A revised endpoint for ceramics desalination at the archaeological site of Gordon-

12 Turkey. Studies in Conservation 2001; 46: 81-92.

13 Watt D.; Colston B. Investigating the effects of humidity and salt crystallization on medieval

14 masonry Building and Environment 2000; 35:737-749.

15 Winkler, E.M., Stone in Architecture: Properties, Durability, 3rd ed. Springer-Verlag, Berlin, 16 (1997) pp. 309. 


\section{FIGURE CAPTIONS}

2 Figure 1. a) Slab of the sandstone after the carving of the central area made in order to enhance

3 the contamination process in this area and in order to simulate a relief too. In this picture, the

4 plastic film covering the neighbouring areas is shown. b) Dimensions (in mm) of the slab and

5 the differentiate areas (central and neighbouring). c) A schematic drawing of the steps followed

6 during the salt contamination process of the central area. d) Slab of the sandstone at the end of

7 the contamination cycles. In this picture the central area shows a great quantity of efflorescence

8 Figure 2. Location and names of the samples taken before the desalination test (represented with

9 grey triangles, referring the samples with a first letter B) and after the desalination test

10 (represented with black circles, referring the samples with a first letter A). Letter C refers to

11 samples taken from the central area and letter $\mathrm{N}$ refers to samples taken from the neighbouring

12 areas. The areas filled with different fills and with a contour with dash lines show the area of the

13 samples extracted by chisel and hammer.

14 Figure 3. Desalination test setup, a) real picture and b) schematic draw.

15 Figure 4. Resistance (in $\mathrm{k} \Omega$; a) and Current Intensity (in $\mathrm{mA}$; b) data recorded during the 16 desalination test for the upper (represented with dash lines and squares) and the lower rows of 17 electrodes (represented with continuous lines and triangles). Data corresponding to each 18 poultice application is shown in different colours.

19 Figure 5. Average amount (4 samples) of removed chloride (a), nitrate (b) and sulphate (c) (mg

20 ion / $\mathrm{kg}$ of poultice) in the poultices applied during the treatment at the anodes and cathodes

21 located at the upper and lower rows. Also, the total content of anion removed after the treatment

22 in each electrode ( $\mathrm{mg}$ ion / $\mathrm{kg}$ of poultice) is shown.

23 Figure 6. Appearance of the rock after the desalination treatment. 


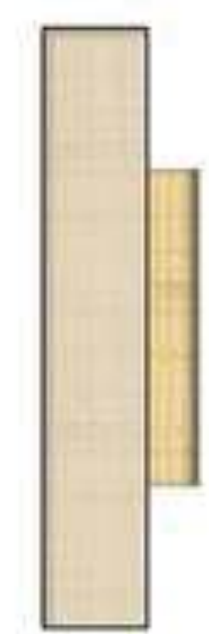

$=$

(ง

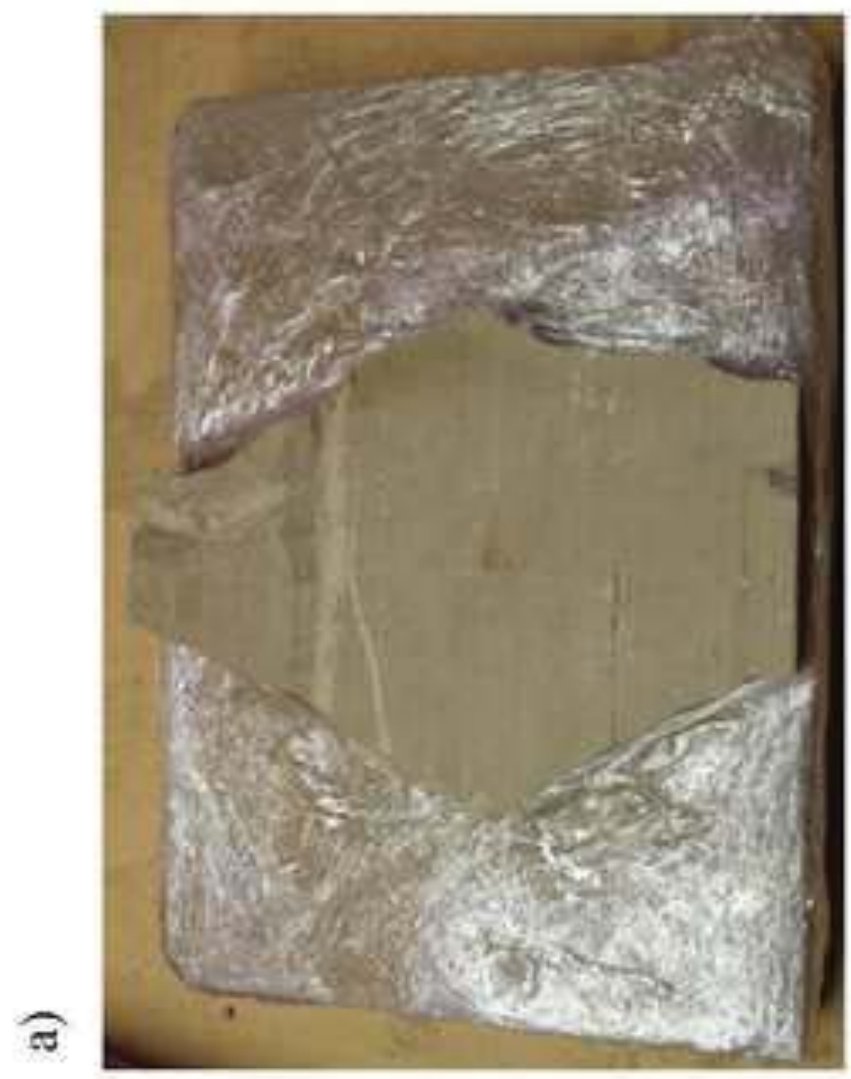

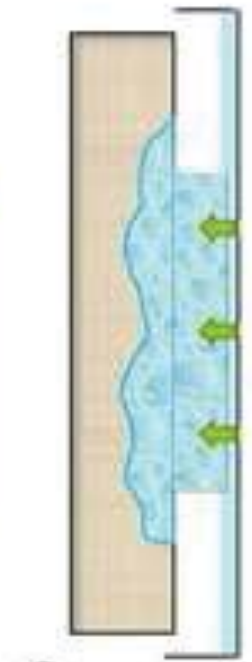

สิ

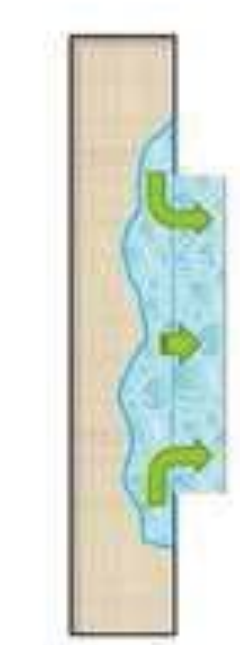

क
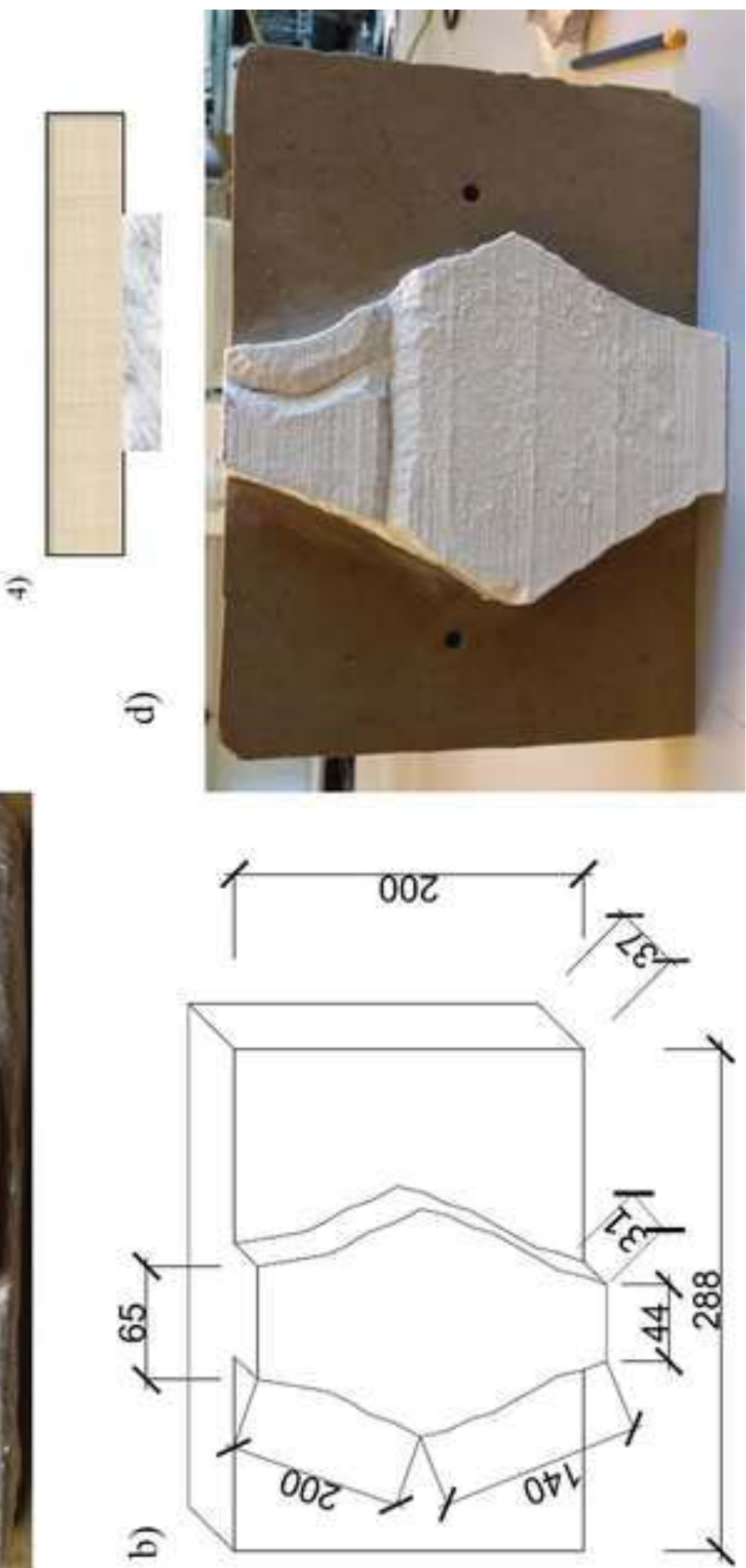


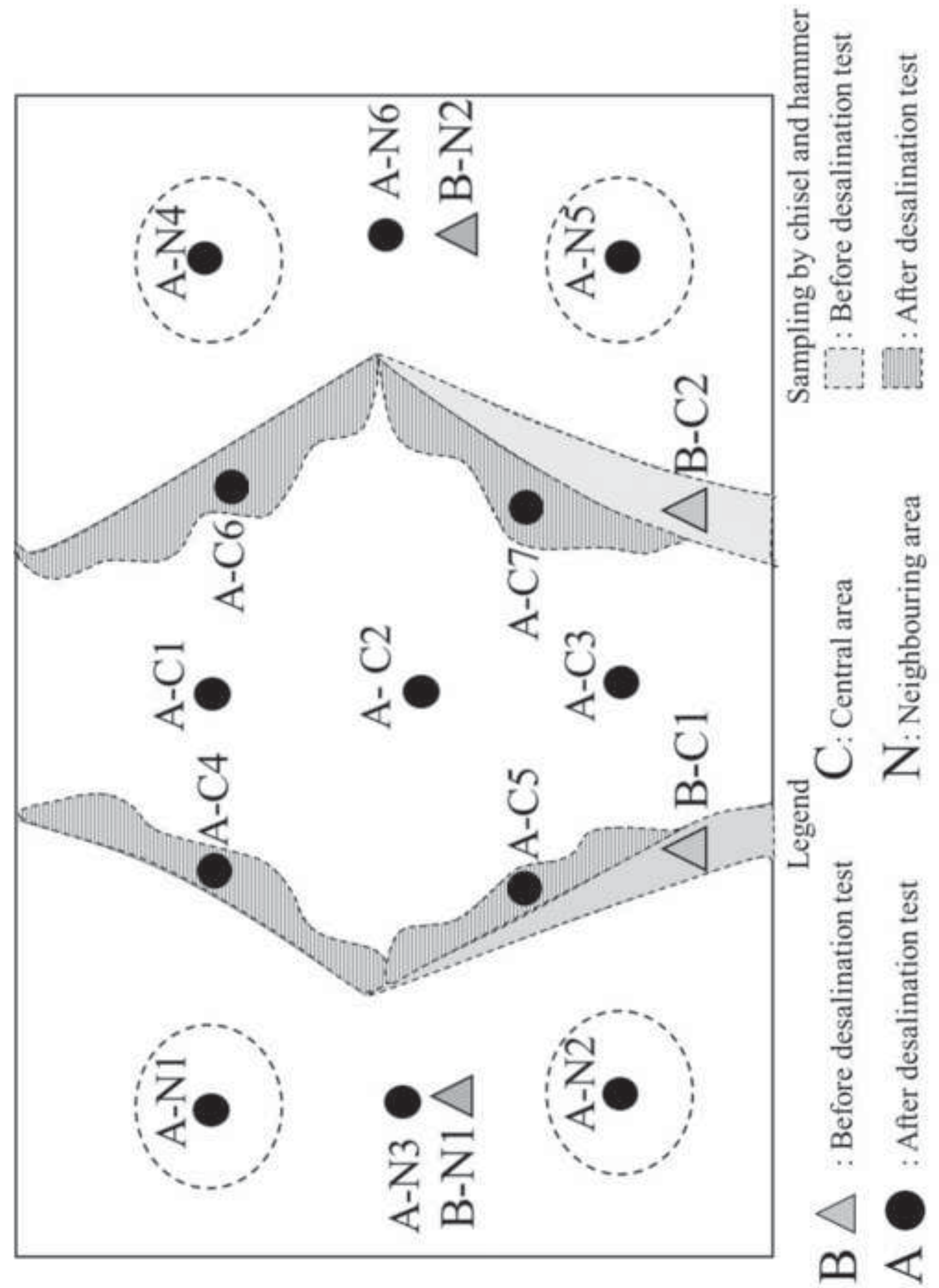

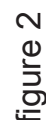

HNm 

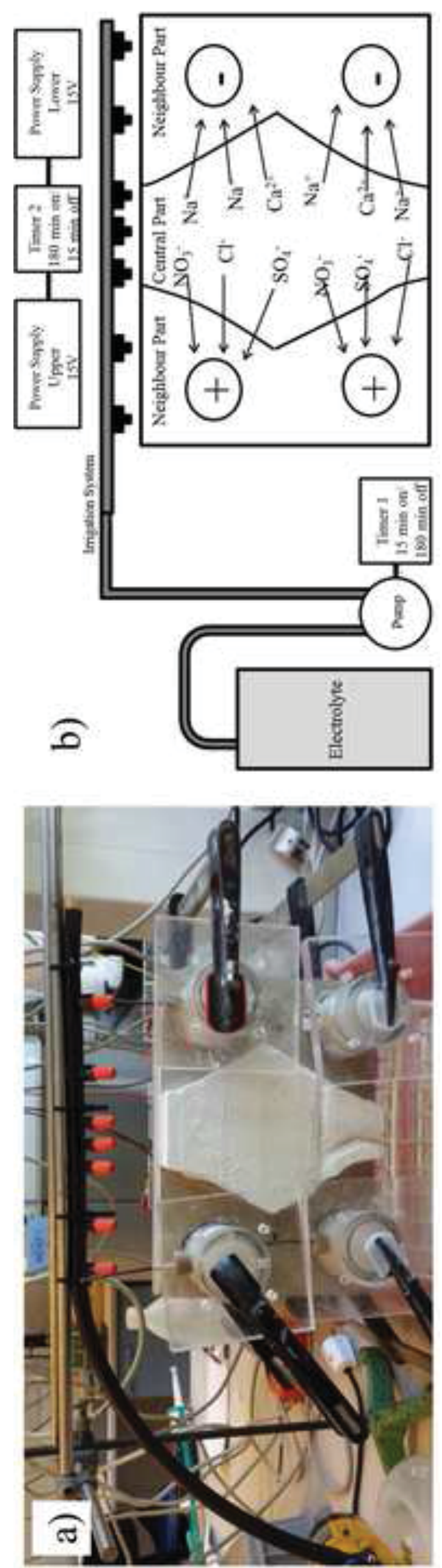

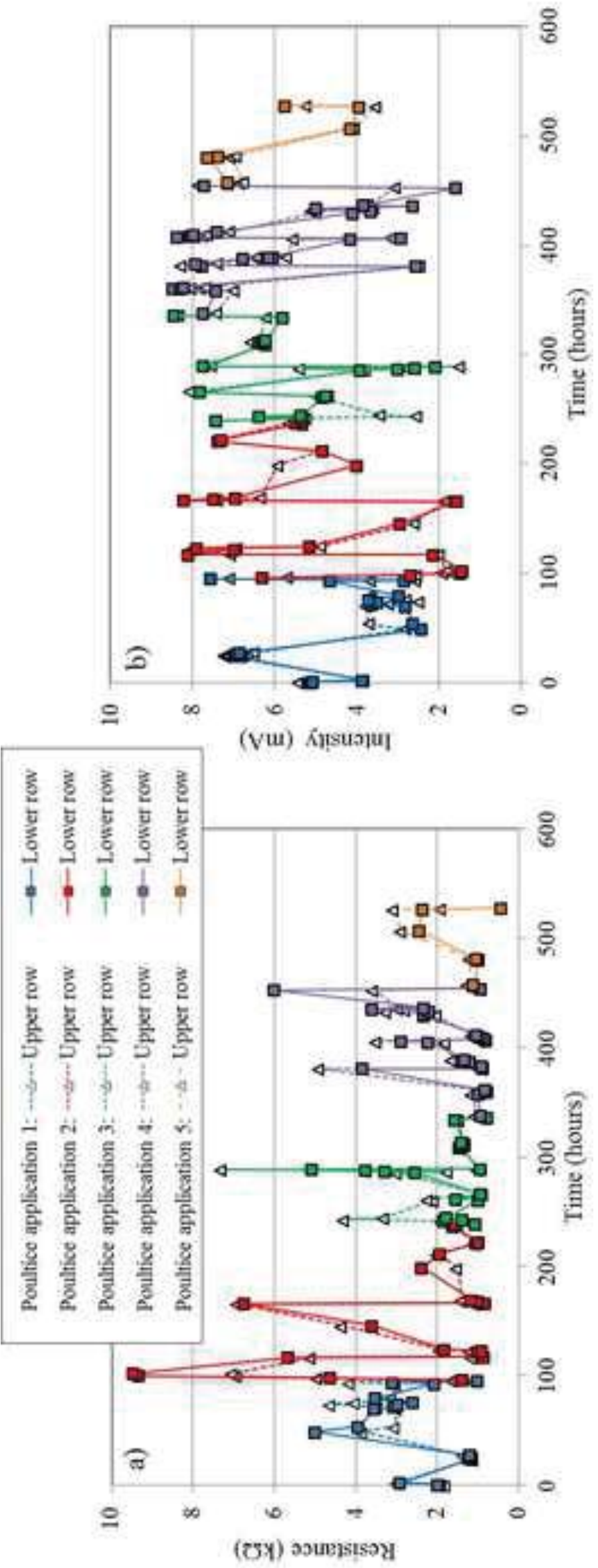

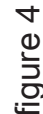

HNmナம0 
1

2

3
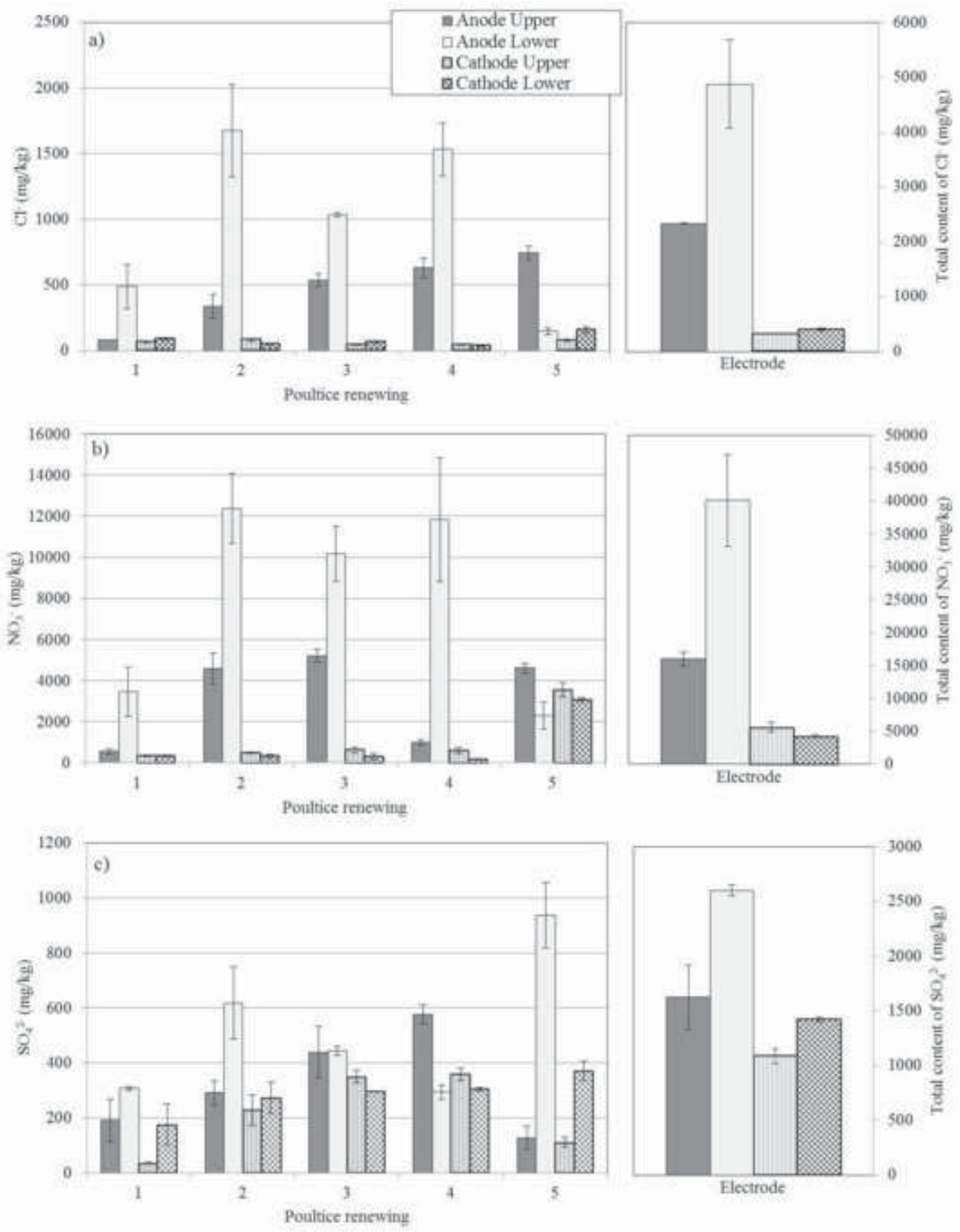


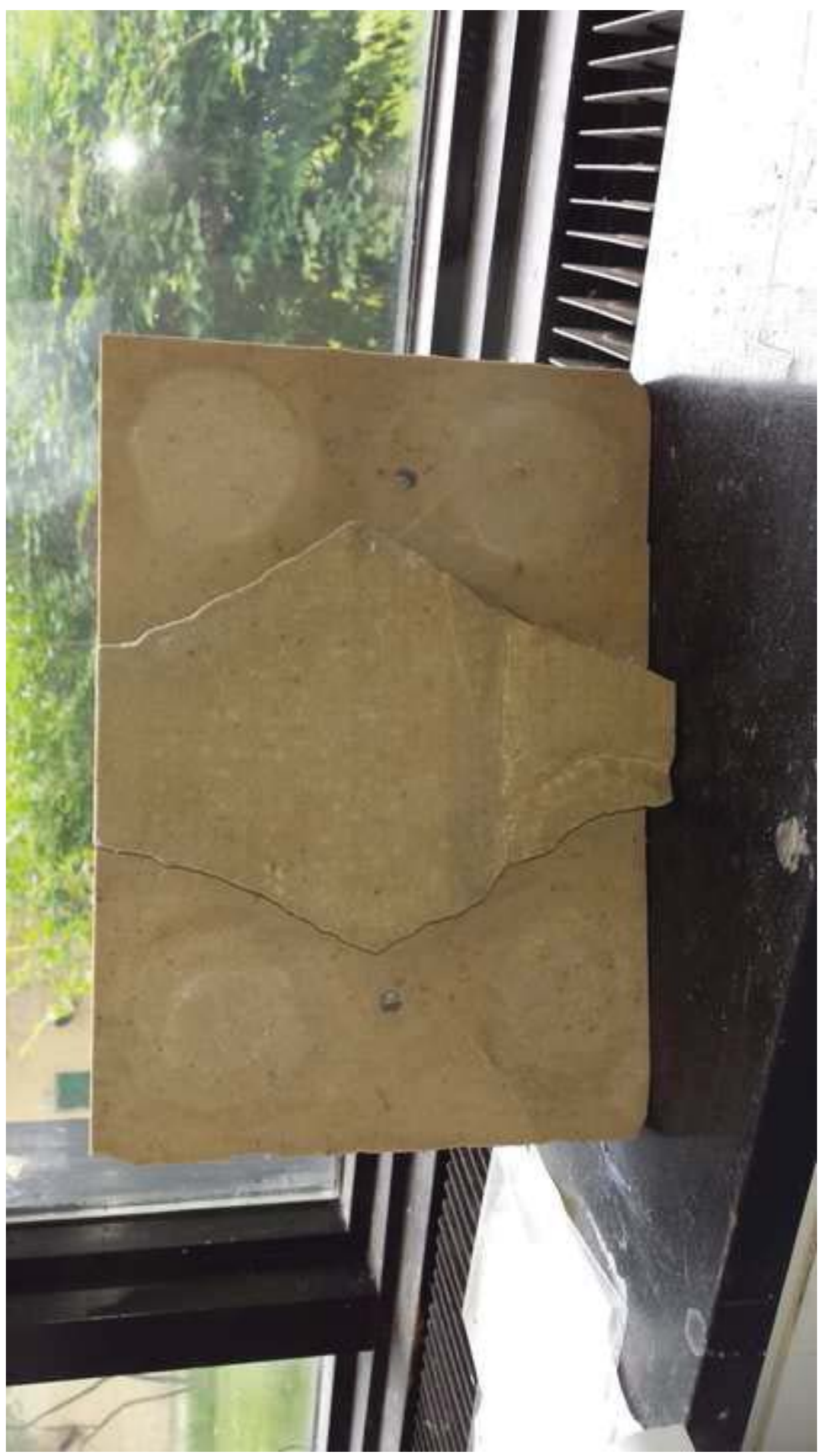

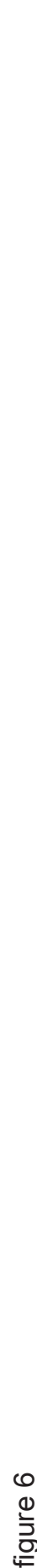

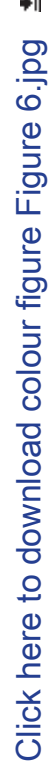

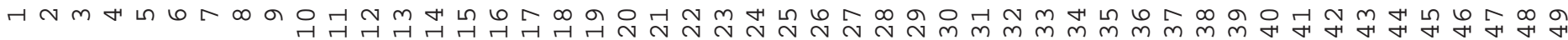


Table 1. Physical properties of the sandstone.

\begin{tabular}{|c|c|}
\hline Water accessible porosity [\% v/v] & $13.24 \pm 0.31$ \\
\hline Mercury accessible porosity[\% v/v] & $17.30 \pm 0.15$ \\
\hline Capillary porosity [\% v/v] & $11.47 \pm 0.25$ \\
\hline Water absorption coefficient (by immersion) [\% w/w] & $6.07 \pm 0.15$ \\
\hline Water absorption coefficient (by capillarity) [\% w/w] & $5.32 \pm 0.13$ \\
\hline Capillarity coefficient C [Kg/m $\left.{ }^{2} \mathrm{~s}^{0.5}\right]$ & $0.046 \pm 0.001$ \\
\hline Saturation degree (by immersion) [\%] & $99.31 \pm 2,17$ \\
\hline Saturation degree (by capillarity) [\%] & $87.58 \pm 0,33$ \\
\hline
\end{tabular}

Table 2. Anion content of the samples taken in the central area (C) and in the neighbouring areas $(\mathrm{N})$ before $(\mathrm{B})$ and after $(\mathrm{A})$ the desalination treatment. The results are compared with the values set by the Austrian standard Önorm B 3355-1 (**: a high risk of crystallization, *: the individual evaluation for crystallization is advised). The effectiveness of the anion removal in percentage is also shown.

\begin{tabular}{|c|c|c|c|c|c|c|c|c|c|c|c|c|}
\hline \multicolumn{13}{|c|}{ Central area } \\
\hline & \multicolumn{2}{|c|}{ Before treatment } & \multicolumn{10}{|c|}{ After treatment } \\
\hline $\begin{array}{c}\text { Ion content } \\
(\mathrm{mg} / \mathrm{kg})\end{array}$ & $\mathrm{B}-\mathrm{C} 1$ & $\mathrm{~B}-\mathrm{C} 2$ & $\mathrm{~A}-\mathrm{C} 1$ & $\mathrm{~A}-\mathrm{C} 2$ & \multicolumn{2}{|c|}{$\mathrm{A}-\mathrm{C} 3$} & \multicolumn{2}{|c|}{$\mathrm{A}-\mathrm{C} 4$} & \multicolumn{2}{|c|}{$\mathrm{A}-\mathrm{C} 5$} & A-C6 & $\mathrm{A}-\mathrm{C} 7$ \\
\hline $\mathrm{Cl}^{-}$ & $8889^{* *}$ & $8485^{* *}$ & $1426^{* *}$ & $1362^{* *}$ & \multicolumn{2}{|c|}{$631^{*}$} & \multicolumn{2}{|c|}{$1517^{* *}$} & \multicolumn{2}{|c|}{$1495^{* *}$} & $1150^{* *}$ & 251 \\
\hline $\mathrm{NO}_{3}^{-}$ & $158970^{* *}$ & $159449^{* *}$ & $28608^{* *}$ & $15489^{* *}$ & \multicolumn{2}{|c|}{$11839^{* *}$} & \multicolumn{2}{|c|}{$16550^{* *}$} & \multicolumn{2}{|c|}{$28069^{* *}$} & $12698^{* *}$ & $14253^{* *}$ \\
\hline $\mathrm{SO}_{4}^{2-}$ & $2262^{* *}$ & $2237^{*}$ & $1534^{*}$ & $1468^{*}$ & \multicolumn{2}{|c|}{648} & \multicolumn{2}{|c|}{945} & \multicolumn{2}{|c|}{$3560^{* *}$} & $1927^{*}$ & $1717^{*}$ \\
\hline $\begin{array}{c}\text { Effectiveness } \\
(\%)\end{array}$ & & & $\mathrm{A}-\mathrm{C} 1$ & $\mathrm{~A}-\mathrm{C} 2$ & \multicolumn{2}{|c|}{$\mathrm{A}-\mathrm{C} 3$} & \multicolumn{2}{|c|}{$\mathrm{A}-\mathrm{C} 4$} & \multicolumn{2}{|c|}{$\mathrm{A}-\mathrm{C} 5$} & A-C6 & $\mathrm{A}-\mathrm{C} 7$ \\
\hline $\mathrm{Cl}^{-}$ & - & - & 83.96 & 84.68 & \multicolumn{2}{|c|}{92.90} & \multicolumn{2}{|c|}{82.94} & \multicolumn{2}{|c|}{83.18} & 86.45 & 97.04 \\
\hline $\mathrm{NO}_{3}^{-}$ & - & - & 82.00 & 90.26 & \multicolumn{2}{|c|}{92.55} & \multicolumn{2}{|c|}{89.59} & \multicolumn{2}{|c|}{82.34} & 92.04 & 91.06 \\
\hline $\mathrm{SO}_{4}^{2-}$ & - & - & 32.20 & 35.12 & \multicolumn{2}{|c|}{71.32} & 58. & 23 & \multicolumn{2}{|c|}{-57.34} & 13.88 & 23.27 \\
\hline \multicolumn{13}{|c|}{ Neighbouring areas } \\
\hline & \multicolumn{2}{|c|}{ Before treatment } & \multicolumn{10}{|c|}{ After treatment } \\
\hline $\begin{array}{l}\text { Ion content } \\
(\mathrm{mg} / \mathrm{kg})\end{array}$ & B-N1 & $\mathrm{B}-\mathrm{N} 2$ & A-N1 & \multicolumn{2}{|c|}{ A-N2 } & \multicolumn{2}{|c|}{ A-N3 } & \multicolumn{2}{|c|}{ A-N4 } & \multicolumn{2}{|c|}{ A-N5 } & A-N6 \\
\hline $\mathrm{Cl}^{-}$ & $1367^{* *}$ & $1590^{* *}$ & $597^{*}$ & & & 87 & & 12 & & 176 & & $344^{*}$ \\
\hline $\mathrm{NO}_{3}^{-}$ & $35246^{* *}$ & $32909^{* *}$ & $5772 * *$ & 651 & & 1131 & $6 * *$ & 2016 & & $3318^{*}$ & & $4025^{* *}$ \\
\hline $\mathrm{SO}_{4}^{2-}$ & 35.08 & 38.94 & 292 & & 3 & 69 & & 42 & & 503 & & 587 \\
\hline $\begin{array}{c}\text { Effectiveness } \\
(\%)\end{array}$ & & & A-N1 & A- & & A-1 & & A-N & & $\mathrm{A}-\mathrm{N}$ & & A-N6 \\
\hline $\mathrm{Cl}^{-}$ & - & - & 56.30 & & & 45. & & 92.0 & & 89.00 & & 78.30 \\
\hline $\mathrm{NO}_{3}^{-}$ & - & - & 83.60 & & 50 & 67. & & 93.9 & & 89.90 & & 87.80 \\
\hline $\mathrm{SO}_{4}^{2-}$ & - & - & -733.10 & -68 & .80 & -188 & 0.30 & -981. & & -1193. & & -1408.50 \\
\hline
\end{tabular}

